\title{
Caracterização anatômica e química de folhas de Jacaranda puberula (Bignoniaceae) presente na Mata Atlântica
}

\author{
Maria Bernadete Gonçalves Martins, ${ }^{* 1}$ Anselmo A. Castro, ${ }^{1}$ Alberto J. Cavalheiro ${ }^{2}$
}

${ }^{1}$ Universidade Estadual Paulista, Campus do Litoral Paulista, Unidade São Vicente, Praça Infante Dom Henrique s/n-Parque Bitaru, 11330-900 São Vicente-SP, Brasil,

${ }^{2}$ Universidade Estadual Paulista, Instituto de Química, Depto. de Química Orgânica, Campus de Araraquara, Rua Francisco Degni, s/n, Bairro Quitandinha, 14800-900 Araraquara-SP, Brasil

RESUMO: A espécie Jacaranda puberula (Bignoniaceae) é conhecida popularmente como "carobinha" sendo utilizada na medicina popular em comunidades tradicionais. O objetivo deste trabalho foi realizar a caracterização anatômica e química das folhas de J. puberula. Para a análise anatômica utilizou-se a microscopia de luz e microscopia eletrônica de varredura (MEV). Para a análise química utilizou-se a Cromatografia Líquida de Alta Eficiência (CLAE). O mesofilo é dorsiventral, a epiderme unisseriada com cutícula espessa, tricomas glandulares do tipo peltado e tricomas tectores em ambas as faces da epiderme, parênquima clorofiliano com duas a três camadas de células paliçádicas e quatro a cinco camadas de células formando o parênquima lacunoso, de tamanho pequeno, com muitos espaços intercelulares, hipoestomática com nervura pinada. Os estudos através de MEV evidenciaram a epiderme recoberta com cera epicuticular e glândulas peltadas com maior incidência na epiderme da face abaxial, constituídas por oitos células secretoras apicais. A análise cromatográfica do extrato etanólico evidenciou a presença de fitoquinóides e flavonóides.

Unitermos: Jacaranda puberula, carobinha, Bignoniaceae, anatomia foliar, cromatografia líquida de alta eficiência.

\begin{abstract}
Anatomical and chemical characterization of Jacaranda puberula (Bignoniaceae) leaves present in Mata Atlântica”. Jacaranda puberula is popularly known as "carobinha" and is used in medical practices of many folk communities. The objective of this work was the anatomical and chemical characterization of Jacaranda puberula (Bignoniaceae) leaves. The anatomical analysis was carried through light microscopy and scanning electron microscopy (SEM). For the chemical analysis it was used High Perfomance Liquid Chromatografy (HPLC). Cross and paradermic sections of leaf showed the presence of uniseriate epidermal cells covered by a thick cuticle layer. There are peltate gland trichomes of multicellular type and no gland trichomes (tectores). It was observed that the faces of mesophyll are distinctly. Two to three layers of palisades cells form chlorophylian parenchyma and lacunary parenchyma is formed of four to five layers of small size cells with many intercellular spaces, pinad ribbing, hipoestomatic. The SEM studies evidenced estomata in the abaxial face of the epidermis covered with epicuticular wax. Eight secretory cells covered by cuticle form the peltate gland trichome. The chromatographic analysis of the ethanol extract evidenced the presence of phytoquinoids and flavonoids.
\end{abstract}

Keywords: Jacaranda puberula, carobinha, Bignoniaceae, leaf anatomy, high performance liquid chromatography.

\section{INTRODUÇÃO}

A família Bignoniaceae é constituída por 120 gêneros, com aproximadamente 750 espécies, geralmente tropicais espontâneas da América do Sul, incluindo árvores, lianas, arbustos e raramente ervas (Joly, 1998). Os gêneros mais importantes da família, com ampla distribuição nas regiões tropicais, são Tabebuia e Jacaranda.

Algumas são utilizadas na medicina popular, como a espécie Jacaranda caroba. O uso no combate a infecções é realizado através do banho preparado com folhas e a infusão destas é usada internamente contra sífilis e como depurativo sanguíneo. O macerado das folhas em aguardente é aplicado externamente como cicatrizante e contra úlceras (Hiruma-Lima \& Di Stasi, 2002; Agra et al., $2007 \&$ 2008). A importância da $J$. caroba levou sua inclusão na primeira edição da Farmacopéia Brasileira (Brandão et al., 2006 \& 2008) e um dos fitoterápicos com registro na Anvisa (Carvalho et al., 2008). As espécies deste gênero ainda se encontram sob adequação taxonômica, pois apresentam 
sinonímias. Há uma diferença quando se fala no nome popular jacarandá (espécie arbórea de onde se extrai madeira de lei), que pertence à família LeguminosaePapilionoideae em relação ao gênero Jacaranda sp, pertencente à família Bignoniaceae (Lorenzi, 2001), a que se refere este trabalho.

A espécie Jacaranda puberula apresenta as seguintes características: altura de 4-7 m, com tronco de $30-40 \mathrm{~cm}$ de diâmetro, folhas compostas bipinadas de 20-25 cm de comprimento, folíolos glabros, de 3-5 cm de comprimento. Sua ocorrência é do Rio de Janeiro ao Rio Grande do Sul, na mata pluvial da encosta atlântica. Floresce durante os meses de agosto-setembro junto com o surgimento das novas folhas e a maturação dos frutos que ocorre de fevereiro-março (Lorenzi, 2001).

Existem estudos farmacognósticos com raízes da espécie Jacaranda decurrens e eles indicam, na sua prospecção fitoquímica, a presença de esteróides/ triterpenos, açúcares redutores, amido, mucilagem e saponinas. Estas informações são de grande importância para o controle de qualidade da droga vegetal, pois esta espécie é comercializada em feiras livres e mercados municipais (Oliveira et al., 2003). Em Jacaranda mimosaefolia foi constatada a presença de hidroquinonas nas folhas, sendo o primeiro registro de isolamento deste grupo químico na família Bignoniaceae (Subramanian et al., 1973). Recentemente, verificouse, em ratos, que o extrato hidroalcoólico de suas folhas apresenta significativo efeito antitérmico e hipotensivo (Nicasio \& Meckes, 2005). O extrato metanólico de folhas e gravetos da espécie Jacaranda caucana, mostrou atividade antileucêmica (Ogura et al., 1976), sendo isolado e elucidado estruturalmente um fitoquinóide chamado jacaranona (Farnsworth et al., 1977). Posteriormente, Ogura et al. (1977) isolaram os ácidos jacourámico, jacarádico, jacarândico e o ácido $2 \alpha$-hidroxiursólico das folhas de Jacaranda caucana. Taylor et al. (2006) verificaram ação antitumoral e antiprotease em Jacaranda copaia.

O objetivo deste trabalho foi realizar a caracterização anatômica foliar através de microscopia de luz e de microscopia eletrônica de varredura de Jacaranda puberula (Bignoniaceae), bem como a caracterização química do extrato etanólico de seus folíolos através de cromatografia líquida de alta eficiência (CLAE)

\section{MATERIAL E MÉTODOS}

\section{Coletas e identificação do material botânico}

Os folíolos medianos de Jacaranda puberula foram coletados na região de Itanháem, no litoral sul do estado de São Paulo, em ambiente natural de Mata
Atlântica, colhidos no estágio vegetativo no mês de maio de 2004. A espécie foi identificada pelo Prof Vinícius Castro Souza do Herbário da ESALQ/USP - Escola Superior de Agricultura Luiz de Queiroz da Universidade de São Paulo, sendo depositada no Herbário sob o número de exsicata ESA 13387.

\section{Diafanização}

Os folíolos foram colocados em $\mathrm{NaOH} 5 \%$, trocando-se a solução até que os folíolos ficassem amarelos. Em seguida, efetuou-se lavagem em água, e posteriormente o material foi colocado em solução de hipoclorito de sódio $20 \%$ por aproximadamente 20 minutos. $\mathrm{O}$ material foi desidratado na série alcoólica (etílica), passando-se pelo xilol e realizando-se a montagem das lâminas permanentes. Foi utilizado o corante azul de toluidina aquosa. Para o estudo da venação utilizou-se a classificação do Leaf Architecture Working Group (1999).

\section{Microscopia óptica}

Foram utilizados folíolos completamente expandidos provenientes do estrato mediano da planta para estudar a histologia foliar. Fixação em FAA 50\% por 24 horas, desidratação em série alcoólica (etílica), infiltração em resina sintética (GMA), emblocamento, seccionamento, coloração e montagem de lâminas permanentes. As peças incluídas em resina foram seccionadas em micrótomo rotativo, obtendo-se secções transversais da lâmina foliar nas regiões do bordo, mediana e da nervura principal com $5 \mu \mathrm{m}$ de espessura. Foi utilizado o corante azul de toluidina com borato de sódio a $1 \%$ em $100 \mathrm{ml}$ de água destilada.

Paralelamente, foram efetuados cortes paradérmicos, à mão livre, com material a fresco, para observação de glândulas secretoras e estômatos, em ambas as faces da epiderme.

\section{Microscopia eletrônica de varredura}

Fixou-se folíolos em solução de Karnovsky modificada, composta por paraformoldeído $4 \%$, glutaraldeído $0,5 \%$, em tampão cacodilato de sódio, $\mathrm{pH}$ 7,2, 0,1M e água destilada por uma noite no vácuo. Posteriormente foram feitas três lavagens com cacodilato 0,05M, com duração de 10 minutos cada uma, seguidas pela pós-fixação com tetróxido de ósmio $\left(\mathrm{OsO}_{4}\right)$ por uma noite. O material foi desidratado com acetona seguindo a série de concentrações 30\%, 50\%, 70\%, 90\% e 100\%. $\mathrm{O}$ material foi levado à secagem até o ponto crítico e fixado a um suporte através de um adesivo condutor e em seguida foi metalizado para observação em MEV. 

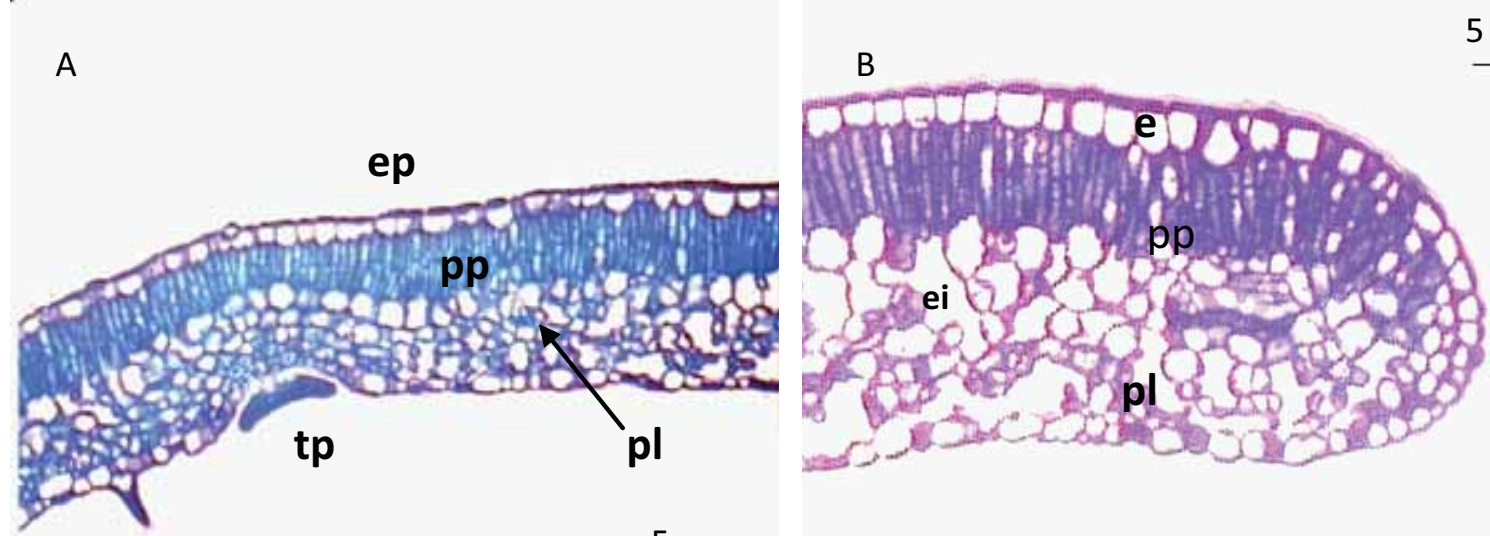

$\mathrm{tt}$

$\underline{5 \mu \mathrm{m}}$
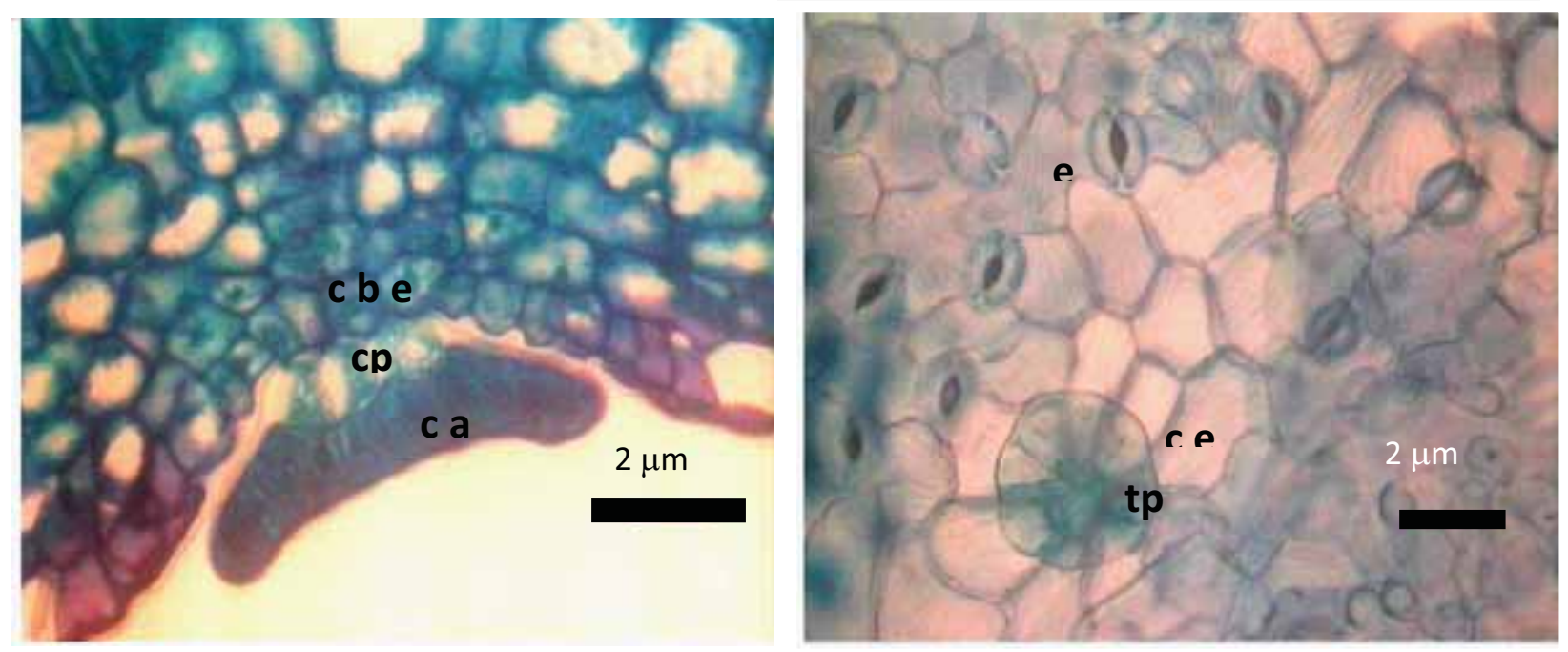

Figura 1. A-B. Secção transversal do folíolo de Jacaranda puberula. A - Região do mesofilo. B - Região do bordo foliar. ep epiderme; pp - parênquima paliçadico; $\mathrm{pl}$ - parênquima lacunoso; tp - tricoma peltado; tt - tricoma tector. C. Secção transversal do folíolo de Jacaranda puberula, evidenciando o tricoma peltado. D. Secção paradérmica do folíolo de Jacaranda puberula na região da epiderme face abaxial. cbe - célula basal epidérmica; cp - célula peduncular; ca - células apicais; tp - tricoma peltado; ce - célula epidérmica, e - estômato.

\section{Análise química}

A análise química foi realizada utilizando cromatografia líquida de alta eficiência (CLAE-DAD), empregando-se $1,00 \mathrm{~g}$ de folíolos de $J$. puberula secos e moídos, colocados em erlenmeyer ( $125 \mathrm{ml})$ com 50 $\mathrm{ml}$ de etanol.O pré-tratamento da amostra, visando a eliminação de interferentes lipofílicos, foi feito por extração em fase sólida (EFS) em coluna de vidro e ativada com metanol-água 95:05 (v/v). As alíquotas do extrato foram retomadas em coluna EFS com eluição foi feita com $5 \mathrm{~mL}$ de metanol-àgua 95:05 e a fração obtida foi filtrada em membrana Millipore ${ }^{\circledR}$ $(0,45 \mu \mathrm{m})$ para análise cromatográfica. Foi utilizado cromatógrafo líquido de alta eficiência Varian ProStar e a aquisição de dados foi feita através do software Stars Chromatography Workstation 5.52, da Varian. O extrato etanólico solubilizado foi aplicado na coluna de vidro juntamente com $5 \mathrm{~mL}$ do eluente.

\section{RESULTADOS}

\section{Microscopia optica e microscopia eletrônica de varredura}

No folíolo da espécie $J$. puberula, cortado transversalmente, foi observada a presença de epiderme unisseriada revestida por cutícula espessa, mesofilo dorsiventral apresenta tricomas glandulares do tipo peltado e tricomas tectores em ambas as faces da epiderme, com predominância desses tricomas na face abaxial (Figura 1 A-B). Os tricomas tectores são multicelulares, unisseriados apresentando formato cônico (Figura 1A). Através de secções paradérmicas 

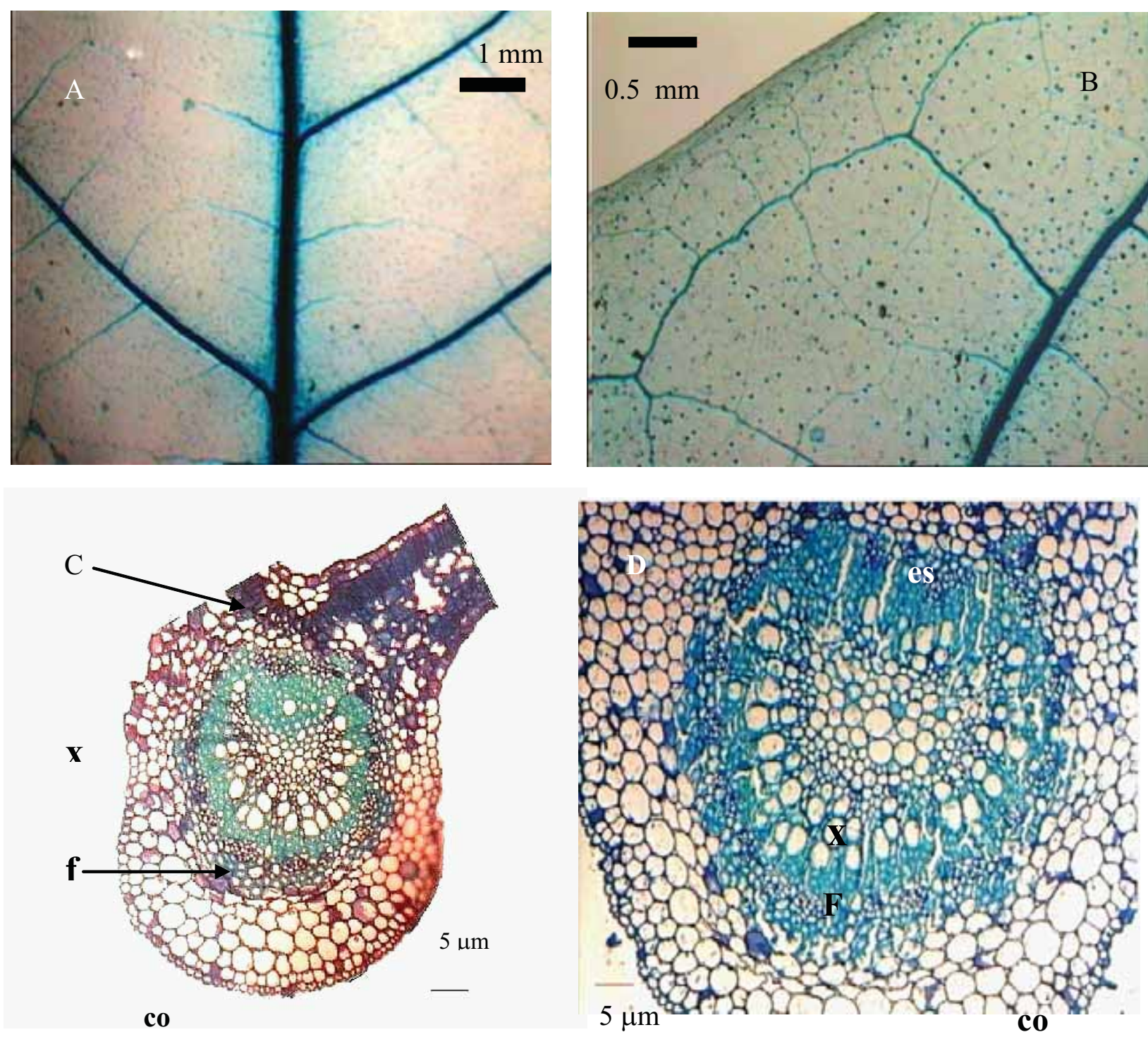

Figura 2. A-B. Diafanização dos folíolos de Jacaranda puberula. A - Região central do folíolo. B - Região do bordo do folíolo. C-D. Secções transversais da nervura do folíolo de Jacaranda puberula. C. Região apical. D. Região Mediana. X - xilema; f floema; co - colênquima; es - esclerênquima.

e transversais (Figura 1C-D) observa-se o tricoma glandular peltado (Figura 1D), apresentando uma célula peduncular curta de parede grossa e um conjunto de células apicais, formado por 8 células secretoras, constituindo a cabeça da glândula (Figuras1 C e D).

O mesofilo é formado por duas a três camadas de parênquimapaliçádico e o parênquima lacunoso apresenta 4 a 5 camadas de células levemente arredondadas e afrouxadas formando muitos espaços intercelulares (Figura 1 A-B). Foram observados estômatos somente na face abaxial da epiderme, o que caracteriza a espécie como hipoestomática, apresentando estômatos do tipo anomocítico e anisocítico, com predominância do tipo anisocítico e células epidérmicas de formato poligonal com paredes levemente ondeadas (Figura 1 D).
O sistema vascular de nervura do folíolo segue um padrão de nervura pinada. $O$ sistema de venação é reticulado com veias secundárias e terciárias anastomosadas formando ângulos randômicos (Figura 2 A-B). A nervura central apresenta-se rodeada por um largo cordão de colênquima (Figura $2 \mathrm{C}$-D). As folhas são compostas, imparipenadas, com folíolos de forma oblonga-lanceolada, ápice agudo a obtuso, base oblíqua e assimétrica e bordo crenado. Os estudos com MEV evidenciaram a presença de tricomas glandulares do tipo peltado (Figura 3D) e tricomas tectores cônicos em ambas as faces da epiderme foliar, com predominância dos mesmos na superfície abaxial (Figuras 3 A, C). Há maior incidência de tricomas tectores nas regiões das nervuras principais (Figura $3 \mathrm{~A}$ ). Observou-se a presença 

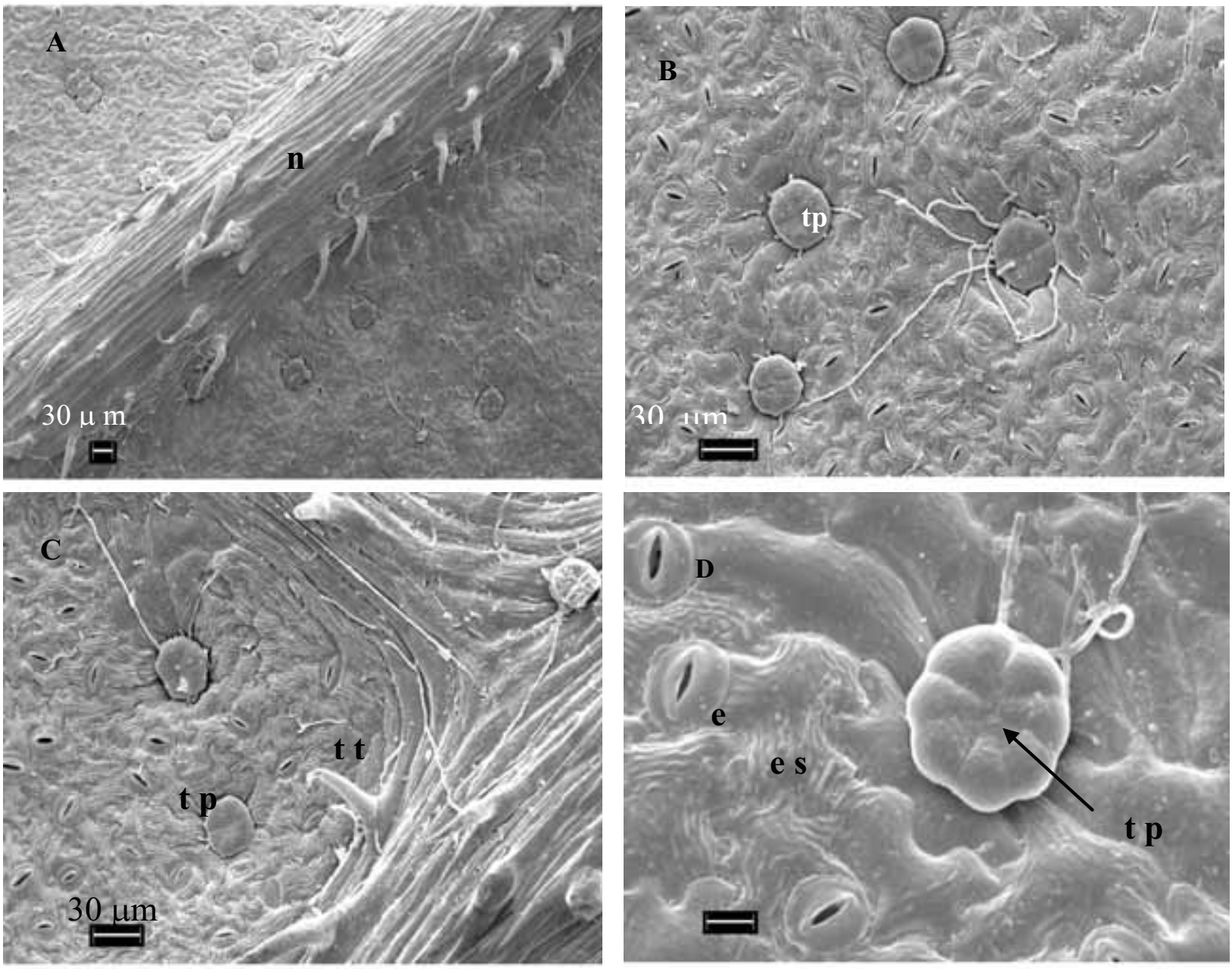

Figura 3. Micrografia eletrônica de varredura do folíolo de Jacaranda puberula na região da epiderme abaxial. n - nervura; tp tricoma peltado; tt - tricoma tector; e - estômato; es - estriação da cera das células epidérmicas.

de cutícula estriada com células epidérmicas poligonais com paredes levemente ondeadas (Figura 3 B-D).

\section{Análise química}

O cromatograma obtido do extrato etanólico de J. puberula, registrado em $254 \mathrm{~nm}$, apresenta vários picos bem resolvidos entre si (Figura $4 \mathrm{~A}$ ), porém sobrepostos a um pico muito largo eluído entre 10 e 20 minutos que pode ser atribuído à presença de taninos. Este fato pode comprometer a qualidade dos espectros no UV obtidos principalmente para os picos 6 a 19. No entanto, a partir de dados fitoquímicos obtidos neste trabalho e em estudos já realizados com espécies do gênero Jacaranda, é possível fazer algumas considerações preliminares.

Os espectros no UV dos picos 1, 2, 3 e 5 (Figura 4 B), com máximos de absorção em cerca de $230 \mathrm{~nm}$, podem indicar a presença de fitoquinóides de estrutura geral I (Figura 4 C). Espectros no UV para os picos 6 a 19 (Figura 5 A-B), provavelmente referentes a mais de uma substância em função da coeluição referida acima, poderiam ser atribuídos a substâncias flavonoídicas em função das absorções em 280 e $330 \mathrm{~nm}$.

\section{DISCUSSÃO}

O uso de caracteres florais e de frutos na delimitação de gêneros, apesar de constituírem os parâmetros mais comumente utilizados na identificação das plantas, não são os únicos que devem ser levados em consideração, pois nem sempre espécimes são coletados com flores ou frutos. Pouquíssima atenção é dada aos caracteres vegetativos na consideração taxonômica de Bignoniaceae, sendo que muitos representantes da família são decíduos ou florescem antes do aparecimento das folhas (Seibert, 1948). Em muitas Bignoniaceae a ocorrência de tricomas glandulares é muito evidente nos tubos da corola (Rivera, 1998). No gênero Lundia, os tricomas secretores de néctar são multicelulares e unisseriados, com uma célula basal inserida na epiderme da corola, apresentam uma célula peduncular, uma cabeça glandular com treze células em média e quatro células 

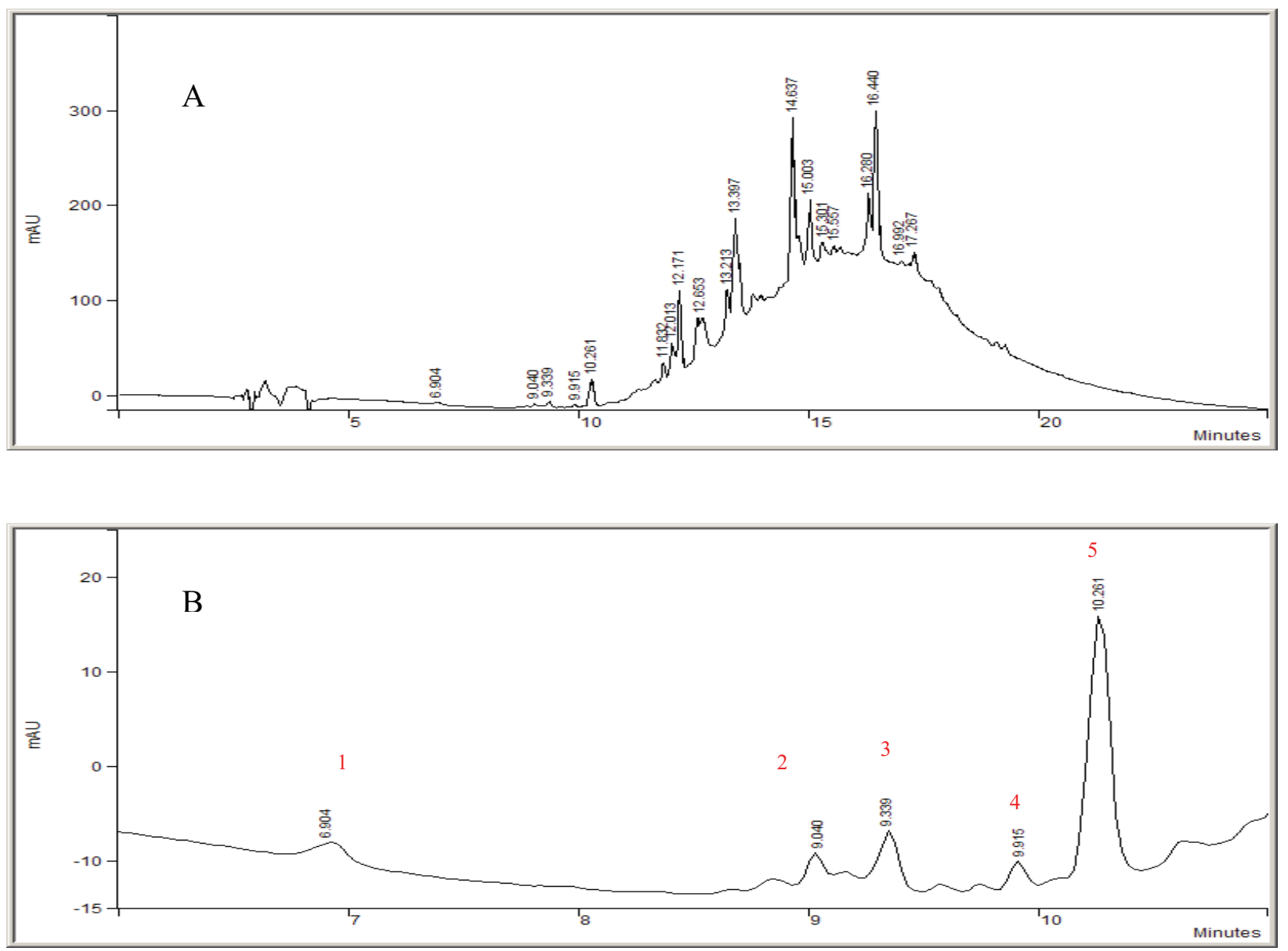

C<smiles>COC(=O)CC1(O)C=CC(=O)C=C1</smiles>

I- jacaranona
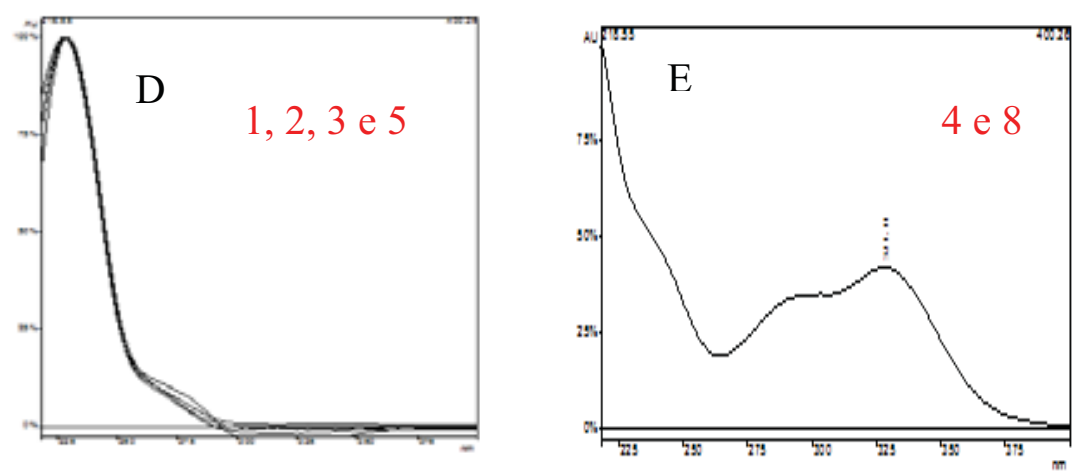

Figura 4. A. Cromatograma do extrato etanólico de folhas de Jacaranda puberula obtidos em CLAE-DAD e registrados a 254 $\mathrm{nm}$. B. Expansão do cromatograma do extrato etanólico de folhas de Jacaranda puberula dos picos 1,2,3 e 5. C. I - Exemplo de fitoquinóide (jacaranona). D. Espectros no UV dos picos 1,2,3 e 5. E. Espectros no UV dos picos 4 e 8.

centrais formando uma tétrade, cercada por células periféricas. Cada tricoma mede aproximadamente 55 $\mu \mathrm{m}$ de comprimento e a cabeça tem diâmetro de $40 \mu \mathrm{m}$ (Lopes et al., 2002). Em Zeyheria montana, os tricomas glandulares são abundantes na epiderme dos ovários. Estes tricomas consistem de uma cabeça secretora com células densamente citoplasmáticas, uma célula peduncular com grande núcleo central, uma célula basal profundamente inserida na epiderme e medem $32 \mu \mathrm{m}$ de comprimento (Bittencourt \& Semir, 2004; Mauro et al., 2007). Segundo Seibert (1948), estudando aspectos florais do gênero Jacaranda, observou que os tricomas glandulares do tipo capitado estão sempre localizados no estaminódio, e pelo seu comprimento relativo, 


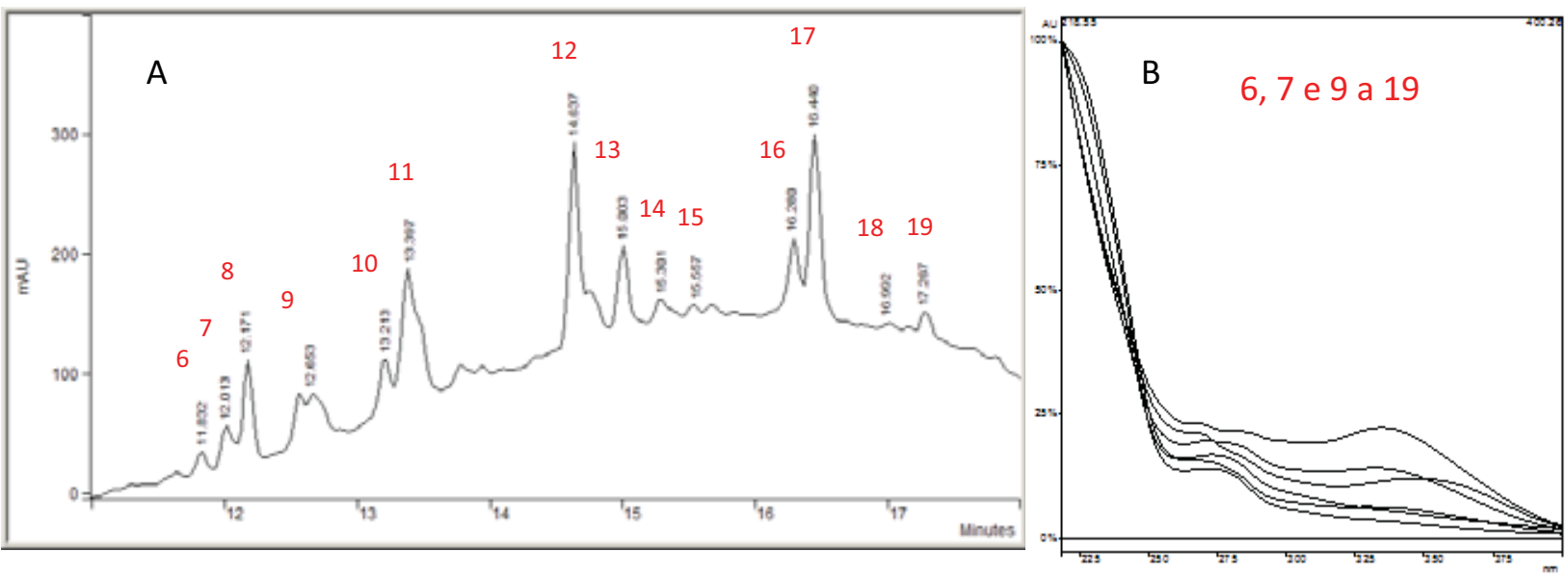

Figura 5. A. Expansão do cromatograma do extrato etanólico de folhas de Jacaranda puberula. B. Espectros no UV dos picos 6 , 7 e 9 a 19.

distribuição e localização, é possível distinguir muitas espécies deste gênero. No presente trabalho, não foi efetuado um estudo nos órgãos reprodutivos da espécie $J$. puberula, pois o objetivo foi apresentar uma opção para a identificação da espécie com base na sua caracterização foliar. Os espectros no UV dos picos 1, 2, 3 e 5 (Figura 4 D) do CLAE-DAD para o extrato etanólico, com máximos de absorção em cerca de $230 \mathrm{~nm}$, podem indicar a presença de fitoquinóides de estrutura geral I (Figura 4 C). Substâncias desse grupo já foram obtidas de outras espécies do gênero Jacaranda (Borges \& Bauer, 1982). De acordo com Taiz \& Zeiger (2002), estes compostos do metabolismo secundário defenderiam a planta do ataque de herbívoros e patógenos, bem como servindo para atração de polinizadores e dispersores, além de atuarem na competição planta-planta, sendo empregados muitas vezes como fármacos (Zuanazzi, 1999).

\section{CONCLUSÕES}

Espécie hipoestomática, apresentando estômatos anomocíticos e anisocíticos, com predominância do tipo anisocítico. $\mathrm{O}$ mesofilo de Jacaranda puberula é dorsiventral, apresentando tricomas glandulares do tipo peltado e tricomas tectores, em ambas as faces da epiderme. O tricoma glandular peltado, apresenta uma célula peduncular curta de parede grossa e um conjunto de 8 células secretoras apicais. A análise cromatográfica evidenciou a presença de fitoquinóides e substâncias flavonoídicas. A caracterização anatômica e química do limbo foliar de Jacaranda puberula permitiu o estabelecimento de parâmetros para identificação em testes de autenticidade e os resultados preliminares obtidos poderão auxiliar pesquisas em relação ao potencial famacológico desta espécie.

\section{AGRADECIMENTOS}

À Fundação de Amparo à Pesquisa do Estado de São Paulo, FAPESP, pela bolsa de iniciação científica do aluno. Ao Prof. Dr. Elliot Kitajima / ESALQ - Universidade de São Paulo, pela utilização do Microscópio Eletrônico de Varredura. À Profa. Dra. Beatriz Appezzato-da-Glória / ESALQ - Universidade de São Paulo, pela utilização do micrótomo.

\section{REFERÊNCIAS}

Agra MF, França PF, Barbosa-Filho JM 2007. Synopsis of the plants known as medicinal and poisonous in Northeast of Brazil. Rev Bras Farmacogn 17: 114140.

Agra MF, Silva KN, Basílio IJLD, França PF, Barbosa-Filho JM 2008. Survey of medicinal plants used in the region Northeast of Brazil. Rev Bras Farmacogn 18: 472-508.

Bittencourt NS, Semir J 2004. Pollination biology and breeding system of Zeyheria montana (Bignoniaceae). Plant Syst Evol 247: 241-254.

Borges PAL, Bauer L 1982. Isolation of ethyl-1-hidroxy-4oxo-2,5-cyclohexadiene-1-acetate from Jacaranda puberula Cham.. Tribuna Farmacêutica 1/2: 49-50.

Brandão MGL, Cosenza GP, Moreira RA, Monte-Mor RLM 2006. Medicinal plants and other botanical products from the Brazilian Official Pharmacopoeia. Rev Bras Farmacogn 16: 408-420.

Brandão MGL, Zanetti NNS, Oliveira GRR, Goulart LO, Monte-Mor RLM 2008. Other medicinal plants and botanical products from the first edition of the Brazilian Official Pharmacopoeia. Rev Bras Farmacogn 18: 127-134.

Carvalho ACB, Balbino EE, Maciel A, Perfeito JPS 2008. Situação do registro de medicamentos fitoterápicos no Brasil. Rev Bras Farmacogn 18: 314-319.

Farnsworth NR, Cordell GA, Ogura M 1977. Phytoquinoid named jacaranon. Ger Offen 12: 123. 
Hiruma-Lima CA, Di Stasi LC 2002. Scrophulariales medicinais. Plantas Medicinais na Amazônia e na Mata Atlântica. São Paulo: Editora Unesp, p. 449452.

Joly AB 1998. Botânica, Introdução à Taxonomia Vegetal. São Paulo: Editora Nacional, p.407.

Leaf Architecture Working Group 1999. Manual of Leaf Architecture - Morphological Description and Categorization of Dicotyledonous and net-veined Monocotyledonous Angiosperms. Washington, DC. Smithsonian Institute.

Lopes AV, Vogel S, Machado IS 2002. Secretory trichomes, a substutive floral nectar source in Lundia A. DC. (Bignoniaceae), a genus lacking a functional disc. Ann Bot 90: 169-174.

Lorenzi H. 2001. Árvores Brasileiras. Nova Odessa: Editora Plantarum, v. 1, p. 41.

Mauro C, Pereira AMS, Silva CP, Missima J, Ohnuki T, Rinaldi RB 2007. Estudo anatômico das espécies de cerrado Anemopaegma arvense (Vell.) Stellf. ex de Souza (catuaba), Zeyheria montana Mart. (bolsadepastor) e Jacaranda decurrens Chamisso (caroba) Bignoniaceae. Rev Bras Farmacogn 17: 262-265.

Nicasio P, Meckes M 2005. Hypotensive effect of the hydroalcoholic extract from Jacaranda mimosaefolia leaves in rats. $J$ Ethnopharmacol 97: 301-304.

Ogura M, Cordell GA, Farnsworth NR 1976. Potential anticancer agents. III. Jacaranone, a novel phytoquinoid from Jacaranda caucana. Lloydia 39: 255-257.

Ogura M, Cordell GA, Farnsworth NR 1977. Jacouramic acid, a new triterpene ester from Jacaranda caucana. Phytochemistry 16: 286-287.

Oliveira TB, Bezerra Netto HJC, Xavier MA, Prado DS, Garrote CFD, Aasquieri ER, Rezende MH, Ferreira HD, Paula JR 2003. Estudo farmacognóstico das raízes de Jacaranda decurrens Cham. (carobinha). Rev Bras Farmacogn 13: 54-55.

Rivera GL 1998. Trichomas y emergências florales em espécies de Bignoniaceae de Argentina. Kurtziana 26: 99-115.

Seibert RJ 1948. The use of glands in a taxonomic consideration of the family Bignoniaceae. Annals of the Missouri Botanical Garden 35: 123-137.

Subramanian S, Nagarajan S, Sulochana N 1973. Hydroquinone from the leaves of Jacaranda mimosaefolia. Phytochemistry 12: 220-221.

Taiz, L, Zeiger, E 2006. Plant Physiology. Sunderland: Sinauer Associates, p.283-306.

Taylor PG, Cesari IM, Arsenak M, Balen D, Adab MJ, Fernandez A, Milano B, Ruiz MC, Willian B, Michelangeli F 2006. Evalution of Venezuelan medicinal plant extracts for antitumor and antiprotease activities. Pharm Biol 44: 349-362.

Zuanazzi JAS 1999. Flavonídes. In: Simões, CMO 1999. Farmacognosia: da planta ao medicameto. Florianópolis: UFSC, p.489-517. 